\title{
AN ANALYSIS OF LEARNERS' SPOKEN ENGLISH IN PUBLIC AND PRIVATE SCHOOLS
}

Lina Vukosi, Cornelia Smit, Eunice Rautenbach \& Gary Collins

Tshwane University of Technology

\begin{abstract}
This study explored the various aspects of Grade 12 English as a first additional language (EFAL) learners' oral proficiency and compared the different aspects of poor oral achievement in selected public and private schools in Gauteng, South Africa. Furthermore, it investigated reasons for the difference in the level of English oral proficiency of the learners in these schools. The difference in the level of English language proficiency was found to be linked to several sociolinguistic factors and environments that exert an influence on the teaching and learning environment.
\end{abstract}

The South African learning environment is characterised by multicultural learners who attain English as a FAL. Public schools are state-governed schools and private schools are independent, often found in the CBD and owned by private stakeholders. The private schools are not necessarily elitist or wealthier than public schools in Gauteng which is a densely populated area. Learners' oral proficiency was compared to determine which environment was perceived to facilitate the desired advanced level of English oral proficiency.

The main question was: Which areas related to the oral English Language proficiency of Grade 12 FET English FAL learners need to be addressed and how does this differ between learners from private and public schools? This study dealt with the learner responses of stakeholders and FET Grade 12 learners in Gauteng in former model-C public schools in Soshanguve and private schools in the CBD of Tshwane. A mixed-methods research approach was followed in order to highlight specific areas and to uncover discrepancies pertaining to poor oral English language proficiency. This is followed by qualitative, semistructured interview responses to clarify the central focus of the study. The findings also confirmed that a limited vocabulary, due to inadequate exposure to English at home was considered the primary cause of the problem.

Keywords: Public school, private school, oral proficiency, education

\section{INTRODUCTION}

The teaching of language in South Africa has a long and agonising past that was impacted by the end of Apartheid in South Africa in 1992 when Nelson Mandela was released from prison (RED, 2018). It marked a new era of language equality in South Africa with its 11 official languages, yet English remained a prominent language in schools with the aim of facilitating understanding among South African speakers from different home language backgrounds (Wolhuter, 2013:104) and has remained a crucial subject to focus on. 
The perception exists that parents favour private schools over public schools for several reasons, one being that private schools generally equip learners to be more orally proficient than public schools do. If the school environment does not meet learners' needs, the quality of their oral proficiency will be affected significantly since language development can also be linked to better job opportunities in future (Ibrahim, Osman \& Bachok 2014: 274). Recent studies by Yacoob, Osman and Bachok (2014:243) maintain that many of the facilities in private schools are of a higher quality than those in public schools and this has an impact on the academic performance of learners - which will ultimately influence their oral proficiency.

Barnardo (2017:18) compared public and private schools and found that private schools in South Africa had a more challenging academic curriculum, better access to resources such as, books, supplies and computers, and learners have a more established network to support them after school. Historical considerations also provide insight into the use of English and the level of performance in English at schools. Multicultural schools in a black environment lack the infrastructure to put them on a par with public schools (Wolhuter, 2013:115) and poor English proficiency in these schools influences academic performance. In addition, learners from private schools tend to excel at English because most of their subjects are taught in English and teachers do not allow code-switching or code-mixing to take place in the classroom (Schmitt \& Underwood, 2004:173-189).

Despite the above-mentioned evidence that a lack of English language proficiency affects academic development negatively, research is silent on the specific problem areas of English proficiency - to provide solutions and to determine the state of affairs regarding the difference in English proficiency when comparing public and private schools. A study conducted by Baddeley (2003:189-208) on English oral proficiency revealed that the level of oral proficiency in private schools was perceived to be higher than in public schools. It was observed that learners in public schools were demotivated and often wasted opportunities to practise English - afforded to them at school. English teachers' command of English can also lead to learners' poor English proficiency due to learners' tendency to copy poor English. Nel and Müller (2010:640) studied English teachers' use of English in South African public schools and found that they lacked sufficient mastery of English grammar.

This study will commence with a brief literature review incorporating a theoretical framework followed by the research methodology, research findings and a discussion.

\section{LITERATURE REVIEW: THEORETICAL FRAMEWORK}

The language learning theories of Bronfenbrenner and concepts adopted from sociolinguistic theory were included to provide a theoretical lens for the study and to elucidate aspects related to the research regarding the two education settings, the subsequent environmental influences, role players such as teachers and even the home environment. Bronfenbrenner's (1976) ecological systems theory is also suitable as a theoretical lens to illuminate the two different educational environments as well as the home environment.

The theory of ecological systems involves the specific position of children nested within the various levels of systems and how their positions and attitudes affect their lives (Leonard, 2011:987). The ecosystemic model layout embraces the various levels and incorporates the microsystem (the face-to-face communication of stakeholders with the child), the mesosystem (the network relationship that exists amongst peers, home, school and church), the exosystem (managements, departments, family social networks and the Department of 
Education), the macrosystem (norms, culture and socioeconomic factors and politics) and the chronosystem (historical influences and aspects of time).

Bronfenbrenner's ecosystemic theory is relevant since the Grade 12 learners form part of a microsystem and are embedded within the mesosytem because they communicate with peers and other learners when learning English as a first additional language (FAL). They are managed indirectly by the decisions taken at a national level by the Department of Education (DBE) which constitutes the exosystem. The theory is also relevant as it indicates that the interrelationships that impact language development and even historical influences as part of the chronosystem cannot be ignored, since they undeniably influence the way learners react to learning English as FAL (Bronfenbrenner, 1994).

Sociolinguistics is relevant since the difference between educational regions of public and private schools also involves a social and economic class distinction (Yacoob, Osman \& Bachok, 2014:243). Stroud (2014:301) observes that the evidence of apartheid-era social behaviour in South Africa can be detected when focusing on social, economic and educational privileges previously enjoyed mainly by the white upper- and middle-class. These privileges included access to prestigious forms of the dominant language i.e., the usage of English in private schools which also involves a unique culture.

\section{SURVEY OF LITERATURE ON ENGLISH LANGUAGE TEACHING IN SOUTH AFRICAN SCHOOLS}

\section{Oral Proficiency in SA Schools}

Since English is included as a subject in all secondary schools in South Africa, it follows that all learners will have similar needs. These needs encompass passing examinations to move to the next grade and matriculating from school. The general requirement is that learners can speak and have conversations in English. From a communicative perspective, speaking is closely related to listening. The interaction between these two skills is shown in conversations (Brown, 2001:275-276).

The school environment is a nucleus of society and school development should be planned based on a sustainable educational context. Research by Ibrahim, Osman and Bachok (2014:274) reveals that academic performance is the most important criterion taken into consideration when parents select a school for their children.

It is important to distinguish between the foreign and naturalistic context. The foreign context is where the target language is taught in the school environment. The teacher, who might not be a native speaker, provides material in the target language that learners must master. The naturalistic context is where the target language dominates and is used at all levels of society. It can thus be deduced that in South Africa, teaching English to FAL learners takes place in a foreign context (Bylund \& Oostendorp, 2014:270). Foreign contexts such as the public and private school contexts are discussed next.

As stated in the CAPS (DBE, 2015:7-10) as part of the School Based Curriculum, the purpose of the English subject in senior high schools is to develop communicative competence in spoken and written English through the development of related skills. The CAPS (DBE, 2015:7-10) document is clear on what is required of learners in the FET phase: Regarding learners' oral development and for assessment purposes a listening test, an oral 
response to texts as well as prepared and unprepared speeches are required as part of their oral marks.

\section{Second Language Acquisition (SLA)}

According to Mcroy (2009:2), children acquire language by listening to their parents using the mother tongue. Children develop oral proficiency in infancy from cooing to using holophrases which are phrases picked up by rote learning until they can use short words. Mcroy (2009:2) asserts that the language taught at school basically equips learners with the needed resources and the correct words or sentences to put across the intended meaning. The home language (L1) provides the basis for the child to 'scaffold' and develop the ability to learn another language. Cummins (2001:17) asserts that a strong foundation in L1 is needed to ensure a transfer of skills to a second language. Cook (2001:33) reveals that learners master a second language faster when formal learning occurs in their first language before learning the L2. Setati (2001:253) promotes the use of code-switching by L2 learners in South African classrooms as it can assist them in understanding foreign words that can impact their oral communication faster.

\section{The Language Classroom}

Struben (2004:25) explains that in many South African schools, particularly in rural areas, the language classroom is a setting where the L2 is taught as a subject and where the target language is not commonly used outside the classroom. He regards the school environment as the most important learning environment for students. A healthy classroom environment can promote positive learning behaviour, motivate learners and affect their academic efficacy and adaptation. A positive learning environment can also affect the positive socialisation of students and the stabilisation of social groups.

Prepared and unprepared speaking form part of the CAPS (2015) syllabus. A prepared speech is described as a topic that is researched and prepared for a presentation of approximately three minutes in class. When unprepared, the speech is delivered impromptu. Unprepared speaking makes it possible to hear what the learners can say and how they pronounce words. This is when teachers can identify those learners who need extra help although hampered by the large number of learners per class. Teachers normally let learners do a written assessment task to keep the class busy while they assess learners individually as they do unprepared and prepared speaking. Teachers sometimes allow for peer assessment but learners tend to award such high marks that those assessments cannot really be used as part of the assessment programme.

According to Brown (2004: 271), socialisation is important for the development of oral proficiency and speaking skills are composed of six categories: imitation, drilling, intensity of practising, responsiveness, transactional activities and extensive communication. These activities can all be exercised in the physical classroom at school.

Speaking and listening form part of a two-way process between the speaker and the listener. It is therefore imperative to identify any listening problem and to deal with that timeously to avoid negative attitudes towards language learning. If learners experience listening problems their comprehension abilities are also affected. An able listener is capable of understanding accent, pronunciation, grammar, vocabulary and comprehension simultaneously. Speaking involves listening, as speakers cannot respond to a remark or question unless they have 
listened by interacting in a social context. Speaking is regarded as one of the most important productive skills in acquiring a L2 (Rao, 2019:6). It involves the communication and expression of viewpoints (Dan, Smatt \& Perkin, 2015:288). Classen (2010:131) posits that listening should be viewed as a fluency activity whereby learners reflect their understanding of a text rather than the accuracy thereof.

Contextualisation is regarded as a crucial motivational aspect linked to learning a language via the listening skill (Colombo \& Furbush, 2009:38). Chou (2015:193) highlights the fact that listening skills and the appropriateness of texts for listening practice have been areas of neglect in research studies on second language acquisition. The appropriate text must serve the purpose of developing listening skills.

\section{RESEARCH QUESTIONS}

The research questions that guided this study are:

- What are the areas in oral proficiency that need attention?

- How does the Grade 12 FET English L2 learners in private schools differ from those in public schools?

- What is the level of oral English proficiency of Grade 12 English L2 learners in selected private and public schools in Gauteng?

The research questions led to the objectives. They are mentioned next.

\section{OBJECTIVES OF THE STUDY}

The objectives of this study were to determine the causes of the difference in the Grade 12 FET L2 learners' English oral proficiency in public and private schools and to determine the level of oral English L2 proficiency of Grade 12 learners in selected private and public schools in Gauteng.

\section{RESEARCH METHODOLOGY}

A mixed-methods approach was used involving both quantitative and qualitative approaches. Bless, Higson-Smith and Sithole (2013) assert that a mixed-methods study is done when one research approach is supported by another to provide more detail regarding the phenomena being studied. The quantitative part involved the marks given by teachers as expert raters; the qualitative part involved the responses of stakeholders to elucidate the problems identified regarding poor oral performance. The data were analysed and themes were identified.

\section{Design}

A research design is the approach used in collecting data from participants (Welman, Kruger \& Mitchell, 2007; Maree, 2007). A case study is used to extract multiple perspectives to underscore the topic of the research (Niewenhuis, 2013). A case study design was used to study the statistical marks as obtained from the target group and thereafter, to reflect on the causes for the problem areas in oral performance by consulting the selected participants. The quantitative statistics were specifically used since they present the breakdown that is required by the DBE to accumulate an oral mark for the FET examination at the end of the year. The statistics were studied to determine areas of poor performance and to probe more deeply into 
these problem areas. Qualitative themes that were informative in this regard are covered to show the participants' reflections on these problem areas.

\section{Data Analysis}

The data are discussed by first providing the graphs as documents, revealing the actual oral marks obtained by Grade 12 learners in private and public schools and assessed by teachers as expert raters. As regards the quantitative part of the study, graphs are briefly introduced, focusing on the problem areas by studying the statistics provided. In addition, the qualitative data that had been extracted during semi-structured interviews were coded and thematically grouped in order to facilitate the discussion on aspects pertaining to the problem areas.

\section{INTERVIEW PARTICIPANTS}

The backgrounds of the participants are provided next. The environment is mentioned and code names are provided. Two private and two public schools were involved in order to produce a realistic sample.

Table 1: Details of participating schools

\begin{tabular}{|l|l|l|}
\hline $\begin{array}{l}\text { Quantitative } \\
\text { population }\end{array}$ & & \\
\hline Schools & Environment & Number of participating learners \\
\hline School A Public & Soshanguve & 53 FET Grade 12 (randomly selected) \\
\hline School B Public & Soshanguve & 50 FET Grade 12 (randomly selected) \\
\hline School C Private & Tshwane CBD & 22 FET Grade 12 (randomly selected) \\
\hline School D Private & Tshwane CBD & 24 (randomly selected) \\
\hline
\end{tabular}


Table 2: Details of interview participants

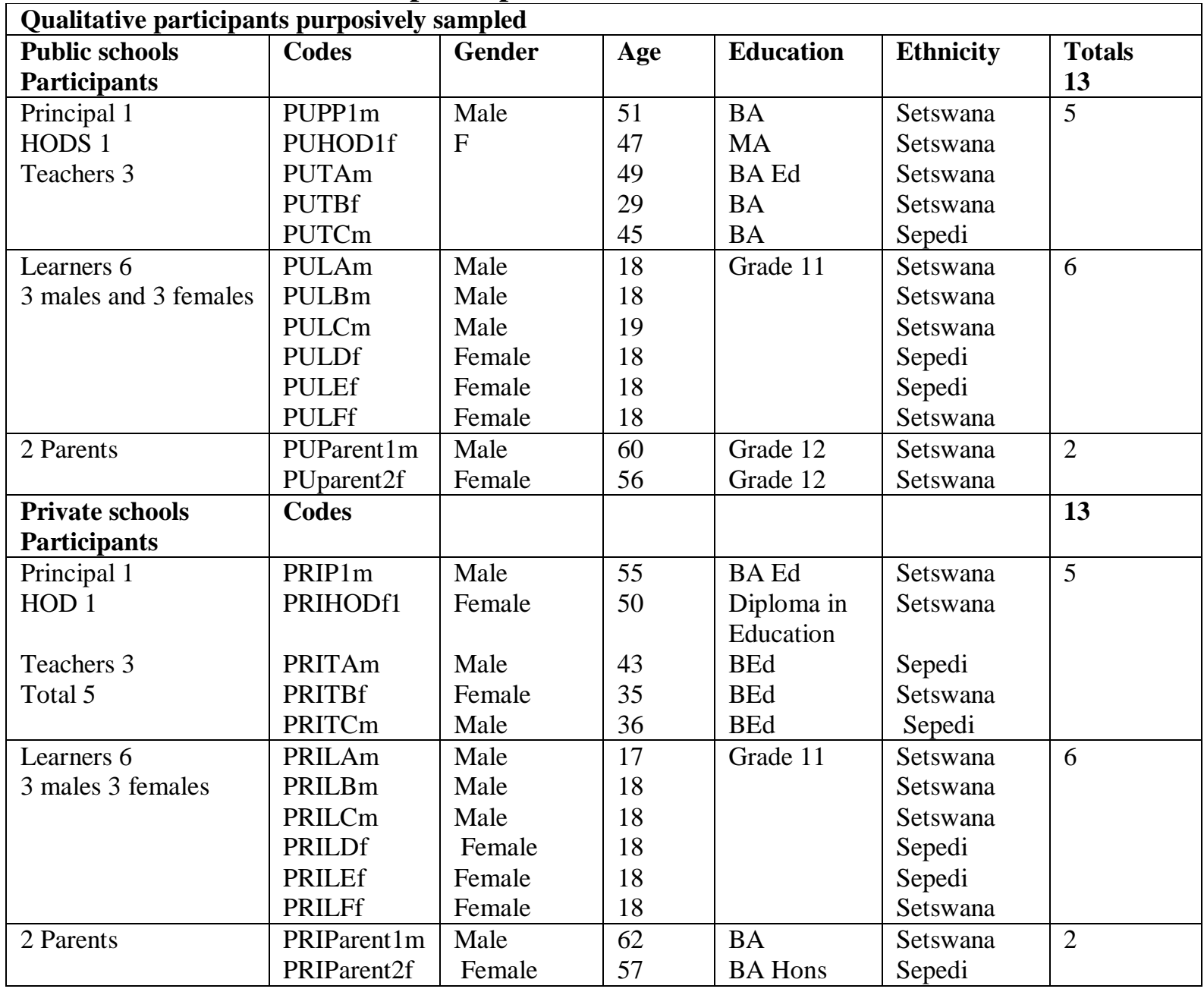

Four high schools participated. The two private schools were from the Tshwane CBD area but they were financially struggling and their school fees were less than R1500 per learner. The parents whose children attended this school were not well-educated and could not speak English ably. This was discovered when visiting the schools at the beginning of the study. The number of learners per class was limited to 30 .

The two public schools were originally model-C schools in Soshanguve. There were approximately 50 learners in the class and parents were reportedly uneducated and had a low income. Interview participants included one principal, one HOD, three teachers, six learners and two parents from both public and private schools. By including both private and public schools, the English oral proficiency results could be compared by studying learners' marks using the DBE's rubrics. These marks were used because they had been awarded by expert assessors from each school who would be more accurate in giving oral marks than the researcher.

A moderated listening test of the teacher's choice was one of the aspects that were taken into consideration. The listening tests were therefore not the same in each of the schools because they had been designed by the respective teachers, however, the tests compared well in terms of the degree of difficulty. Prepared speeches were on learners' own choice of topic and unprepared speech on the teachers' choice of topic, however, the same rubrics were used by all the teachers of both private and public schools as they are prescribed and provided by the 
DBE (2015). It can be argued that no teacher will arrive at the same oral mark, but after many years of experience it can be taken that the teachers were able to rate the performances as experts by using similar rubrics for the indicated tasks.

Interviews were conducted in the staff rooms and the teachers of both the private and public schools made their marks available to the researchers. The reason for involving teachers, parents and learners in the interviews was to derive rich data and provide a detailed description of the problems experienced regarding English oral proficiency performance. Learners are influenced by all the ecosystemic stakeholders including teachers and parents, since learners' attitudes regarding learning can be influenced by communication with their parents as well (Bronfenbrenner, 1986).

The quantitative marks were collected from the relevant schools in order to provide the statistics. The phenomenon of poor oral marks in certain areas of oral proficiency that surfaced in the statistics was then further investigated using interview questions posed to the participants to explain the results. The findings are provided next.

\section{FINDINGS}

\section{Quantitative}

A graph reflecting the oral marks of private schools $\mathrm{C}$ and $\mathrm{D}$ follow next. The rubrics provided by the DBE are clear in what to take into consideration such as clarity, pronunciation, enunciation (expressing words well) and content. School A had 50 and School B 53 learners in total. The sample size was restricted by the number of learners allowed for enrolment as Grade 12 learners.

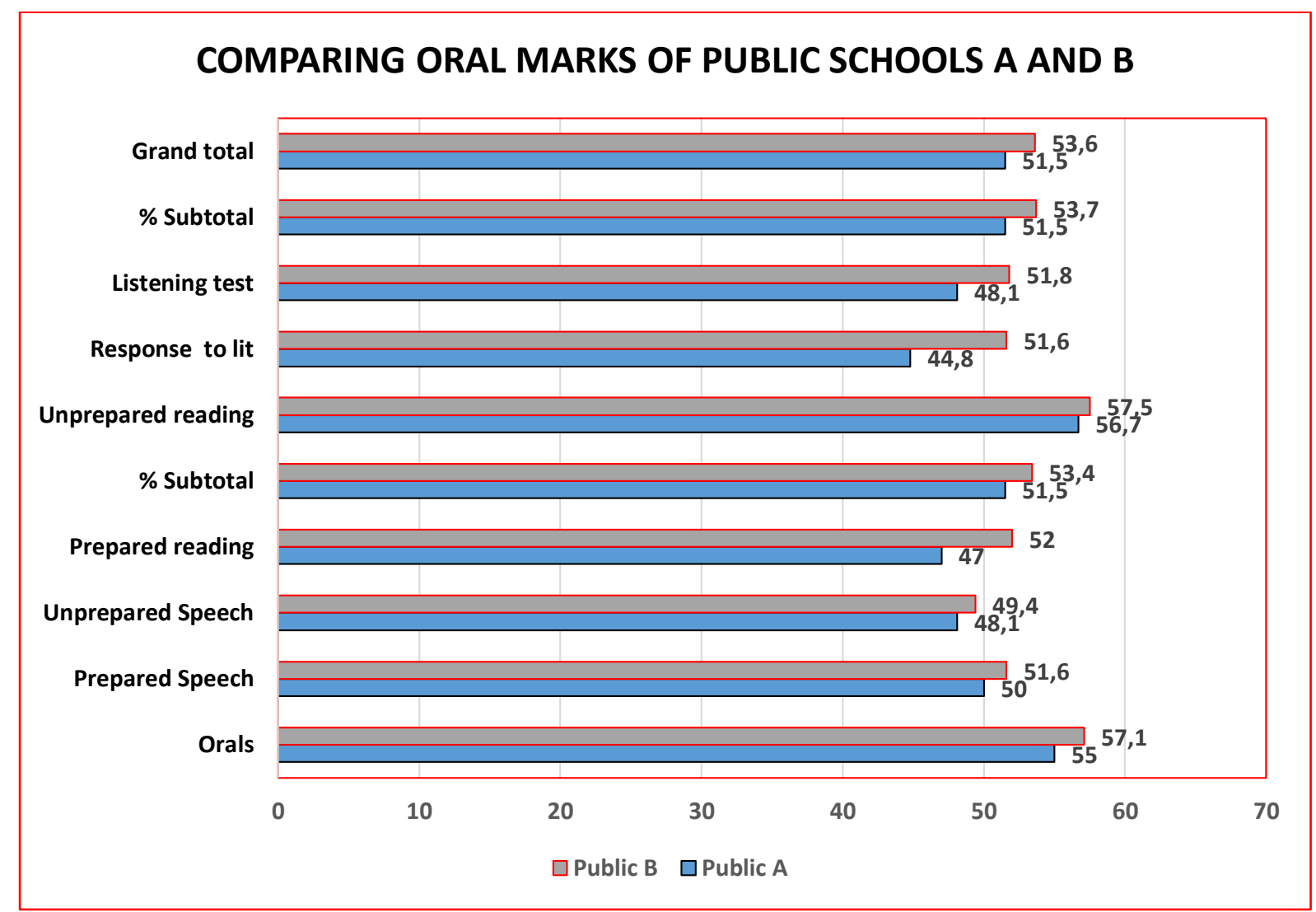

Figure 1: English oral marks of Public Schools A and B 
Figure 1 indicates that the oral proficiency marks of learners in both participating public schools corresponded well. Public School B's overall average was slightly higher at 53,6\% compared to School A with 51,5\%. The area of weakness was unprepared speech where Public School A had 48,1\% and Public School B had 49,4\%. It must be taken into account that learners only had a limited time to deliver the speeches which could also have influenced their marks.

Another area where learners did not perform well was the response to literature and the listening tests. Response to literature involves learners' oral responses to a literary text. Here, learners were required to discuss the content of a chosen text (a magazine article or newspaper report) of their choice and speak fluently on it. These findings correspond with what had been found in the qualitative findings, namely that learners experience problems with listening and producing the correct sounds in English. They also had difficulty in finding the appropriate words when speaking, indicating a lack of vocabulary related to the topic and to share the contents of the speech. The oral results of private schools $\mathrm{C}$ and $\mathrm{D}$ follow next.

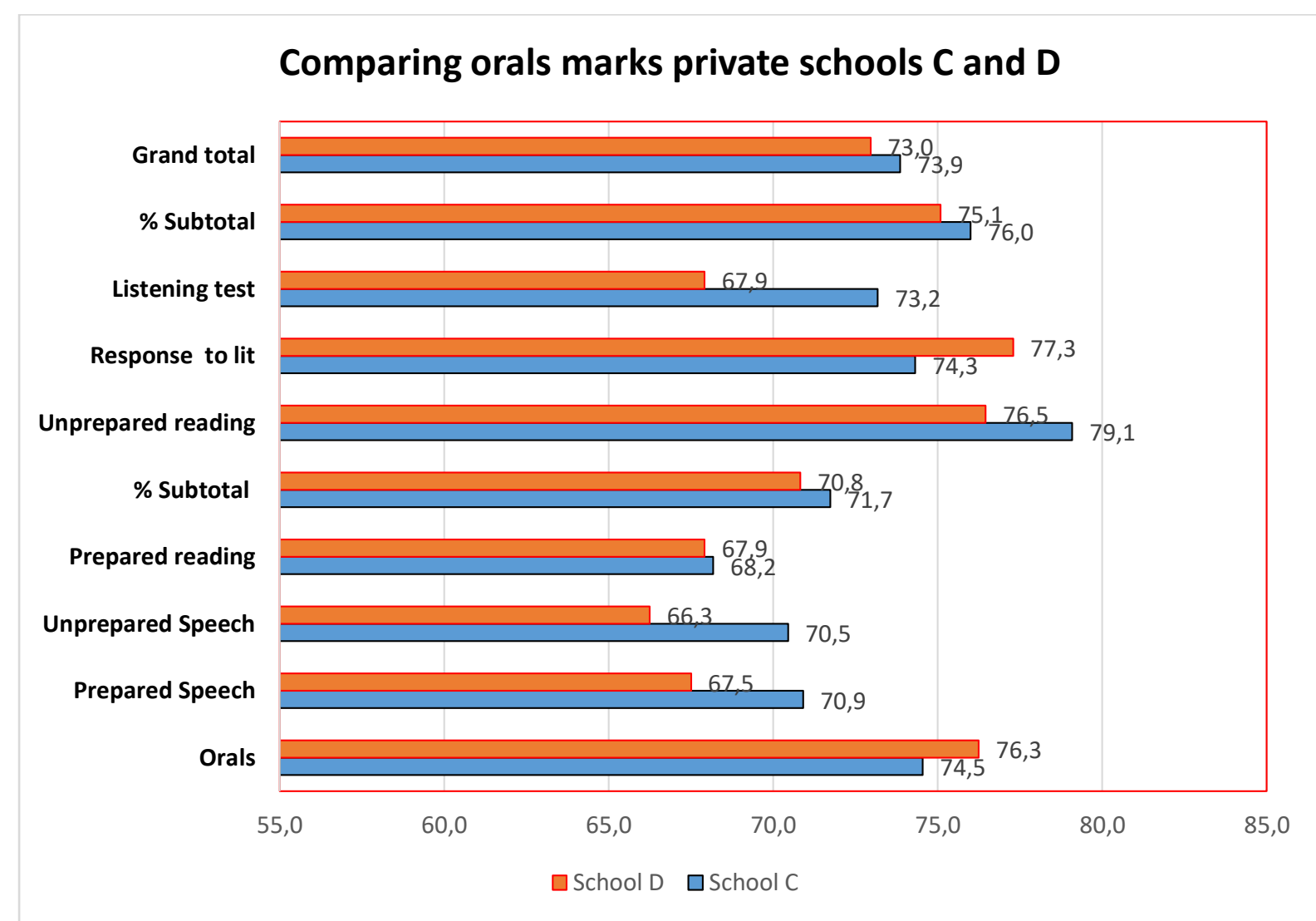

\section{Figure 2: English oral marks of Private Schools C and D}

When studying the marks of the two private schools in Figure 2, the area of weakness for the oral proficiency was unprepared speech, with Private School D at 66,3\% and the listening test for School D was 67,9\%. Private School C's marks are more consistent. When comparing the areas of weakness for the private and public schools it is evident that unprepared speech posed a challenge for both private and public schools. Listening tests were also an area in which all learners performed poorly. It is evident that unprepared speech and listening tests need more attention. Those were identified as the areas that need to be scrutinised in public schools. Learners of both groups performed worse in response to literature than in the other 
areas. The poor marks confirm the qualitative data that learners lack sufficient vocabulary and that they battle with hearing the sounds when doing listening tests.

When comparing the results of the public and private schools, it emerged that the learners from the private schools attained higher marks in the oral tasks overall. The private schools had an average of 51,5\% (Public School A) and 53,6\% (Public school B). The private schools had an average of $73 \%$ (Private School C) and $73.9 \%$ (Private school C), which is much higher.

\section{Qualitative Findings}

The following themes surfaced in the data and are discussed next.

\section{Overlap exists in poor oral proficiency in private and public schools}

When comparing the areas of weakness for the private and public schools, it was evident that unprepared speech posed a challenge for both private and public schools. Listening tests were another area in which all learners performed worse. Listening tests require comprehension as learners listen to a text read aloud and must then answer questions on that text. It is part of the teacher's responsibility to set the listening test pitched at the correct level and to have it moderated and checked at cluster meetings.

This finding was noticeable since both public and private school learners had similar challenges with oral proficiency. It can be assumed that unprepared speech and listening tests need more attention. Response to literature was also an area in which learners of both groups performed worse than in the other areas. Response to literature involved an oral account of a text that they could prepare for. To get a more in-depth understanding of these challenges, a selection of teachers, parents and learners were interviewed regarding the indicated areas of weak oral proficiency.

\section{The influence of the level of education of stakeholders}

The teachers who participated in the interviews all had qualifications ranging from BA, BEd and even Master's degrees. Consoli and Aoyama (2020) underscore the importance of qualified teachers who can speak the L2 well to facilitate language learning. The principals held at least a BA degree. The majority of the teachers had many years of teaching experience. It can be observed that the public school and private school teachers compared well when considering their academic training.

However, the level of education of the home background posed a problem as parents' attitudes towards the target language and their educational level can also contribute to oral proficiency development. If parents are positive about the L2 they can influence their children to be more positive towards using and learning that language (Tavil, 2009). Parents of learners in private schools had higher education qualifications and worked in the CBD which explains why their children attended the CBD private schools. In contrast, the majority of the parents of the learners in public schools worked on farms in the neighbouring areas. The parents who were not well-versed in the target language did not have a high level of education and this may have influenced the learners' language proficiency. 


\section{The influence of language attitudes}

In view of the language history it was reported that learners' mother tongue was their language of preference for the LoLT. The participants all recalled the introduction of a democratic South Africa in 1994 when all eleven languages received equal and official status. English was the second choice (not Afrikaans) since it allowed everyone to communicate and teachers and parents observed the value of communicating in English. The eleven official languages would be the reason why parents/teachers thought instruction in the home language is a good choice (Wolhuter, 2013:108). It therefore follows that language attitudes and motivation also play a role in the development of speaking skills. Motivation is an important influential factor in learning L2 as it impacts learners' attitudes towards learning the language including oral communication in the L2 (Consoli \& Aoyama, 2020).

Staff members of the public schools (PUTAm, PUTBf and PUTCm) reported that it was time to afford indigenous languages the opportunity to receive attention - this view also influenced their attitudes towards teaching English as L2 and could affect learners' oral performance. This corresponds with what is reported by Horsthemke et al. (2013:106) who document new developments regarding languages and the influence of politics, mentioning the eleven official language groups and their independence since democracy.

The language attitudes of the parents of private schools revealed that English oral proficiency was a natural phenomenon to them in the CBD since they used English regularly due to their contact with businesses as part of their jobs where English is used to communicate (Ball, 2017:1). They had more exposure to English in the CBD regarding English than parents from Soshanguve, which may influence their proficiency. Soshanguve is a word coined to represent the many languages spoken in that area. It comprises Sotho, Shangaan, Nguni and Venda (i.e., So-Sha-Ngu-Ve) whereas Soshanguve was called Mabopane East in 1977. The very name communicates that many languages are spoken in the area and English is thus not the primary language to be used by these citizens of a more rural area (Statistics SA, 2015).

\section{Financial challenges as an influential factor in language acquisition}

Reading material is linked directly to the provision of resources and is the most important aspect that shapes and motivates teaching and learning an L2. According to N'Namdi (2005:32), if there is no lack of reading material educationalists find it quite easy and pleasant to create an effective reading environment. Yet, the parents and teachers of the public schools specifically reported the contrary. The teachers (PUTAm and PUTBf) reported that the schools used English prescribed texts. The participating CBD private school had a library that could help to provide English reading material to influence the learners' performance, yet the oral marks were still not very good. The available reading material was up to date and books were observed to be in good condition. Learners were required to buy prescribed books themselves which was a challenge. This may be a reason for the poor performance of the learners regarding response to literature since, to be able to respond to literature, learners need to be exposed to it.

PUTAm (Public school) was of the opinion that:

'It is an indication of good cognitive ability if the learner can read fast. I sometimes engage fast readers to read to the class. We use short stories instead of the Shakespeare since the short stories are closer to the learners' life world. Yet, reading 
or responding to one or two books is not enough to hone skills to be able to respond to literature orally as is required as part of the oral curriculum.'

\section{Listening and speaking}

Listening to the teachers in public schools was almost all the input the Grade 12 L2 English learners had concerning listening to English as they did not communicate in English at home. The teacher taught English and performed the assessment of a listening task as prescribed by the DBE. It was obvious that learners had trouble understanding many of the words and they battled to interpret the foreign sounds which caused them to perform poorly in the listening comprehension test. The teachers reported that they allowed enough time for the learners to listen to the reading of the text which learners then had to respond to. The teachers had to repeat the text and some were still uncertain of what the text was all about. The teacher repeated the listening text to make sure that learners heard correctly. Since it was not the mother tongue of any of the teachers, it could be that they did not always use clear and correct English pronunciation. An additional problem was the teaching of vocabulary.

PUTAm said:

'We focus on engaging learners in writing the high register words connected with the theme on the board, but due to the large number of learners it is not really possible to do proper word attack skills as part of bottom-up reading in groups as the noise of 50 plus learners when communicating. Learners also have fewer opportunities to practise their English oral skills.'

The teacher said that it was difficult to do the listening exercise with 50 learners because they all started asking questions simultaneously when they were unsure of what had been read. The resultant noise could then also have had an influence on their test scores. It also surfaced that teachers tended to resort to direct instruction as teaching strategy because of the class size, especially in public schools. Despite the criticism against direct instruction as teacherdriven strategy, it can be effective in teaching learners when working with larger groups and because of the teachers' specialised knowledge (Renard, 2019).

The learners from the public schools reported that they dreaded doing orals for fear of being ridiculed for their incorrect and odd pronunciation by other learners. They claimed to watch television to learn more words and focus on their pronunciation. Television exposure was nearly their only contact with the spoken word in their home environments. Unfortunately, they could not really practise their speaking skills due to time constraints. Because their peers and teachers spoke poor English it was difficult to develop competency in spoken English.

The two sets of teacher participants were compared when studying the data to determine if there were differences in their approaches and experiences with the learners. Public school teachers believed that learners from public schools performed worse than learners from private schools. In addition, the public school teachers reported that learners do not converse in English since they enjoy their mother tongue and use it most of the time.

PUTBf posited:

'I enjoy role-play as it is then when we can use media to make the lesson interesting and learners can bring something from home to wear and illustrate during role-play. We do drama in matric. It is a play by Athol Fugard.' 
The teacher participants were of the opinion that individual speaking is valuable, particularly in small classes, because each learner can focus and can be afforded the opportunity to speak informally when presenting their prepared speeches.

The teachers' opinions on the reason for learners in public schools being disadvantaged compared to the speaking proficiency of learners in private schools were that teaching speaking skills required first language speakers and none of them were first language English speakers. The teachers at the private schools admitted that they had the advantage of exposure to English mother tongue speaking, since parents and business owners in the CBD were English-speaking and they influenced the way English was used in class and at home.

PUTBf reported that:

'Learners must realise that their learning is their responsibility as many parents in our community do not understand English. Teachers provide them with notes, but they have to study their work.'

PUPPS1m said:

'Learners do not do well in comprehension as they struggle to find the synonyms and the antonyms of the words. They barely understand what the words mean and to use words in the correct sequence of SVO remains another challenge. It is necessary for speaking proficiency as it influences effective communication. We do engage in topdown reading strategies and deal with comprehension tests as part of language teaching. They want to add the pronoun after the noun e.g., the man he sees the bird of prey because of African mother tongue interference.'

Parents reported that they tried to influence their children to practise speaking English, however, the learners from the public schools did not enjoy as much encouragement compared to those from private schools. It was also reported that learners had trouble doing the listening tests. The reasons offered for performing poorly in listening tests were the strange pronunciation of words by the readers and the inability to hear all the English sounds. Furthermore, vocabulary posed problems since learners fell behind in interpreting and synthesising the moment they did not understand certain words. The matter of learners learning at their own pace posed a problem here: for all to listen to one text, they should be able to follow the same pace.

\section{The influence of reading and writing on learners' English proficiency}

Klapwijk (2015:8) observes the problem of poor literacy levels in South Africa and is of the opinion that incompetent readers is one of the most salient aspects that should be addressed since reading development is crucial for citizens to participate in the economy and in society. In this study, it was evident that speaking aloud received much attention as it was favoured over reading. The teachers concentrated on oral reading since learners did not really have many opportunities to use English outside the classroom as the speech community in Gauteng is predominantly Sepedi, IsiZulu and Setswana.

It was thus noted that prereading and actualisation of the preknowledge linking English vocabulary with the learning experience did not receive much attention. Using pictures to teach words was also not really pursued as a strategy. Identifying challenging words received much attention as an isolated strategy. Text-to-text connections were not pertinently taught. Learning from peers did not really benefit the public-school learners whereas peer influence was prominent in private schools. The latter shared reading books, talked about interesting 
authors and topics and enjoyed new technological inventions. Reading from tablets was also popular among private school learners whose parents were able to provide in the needs of their children.

It was found that word recognition strategies that are useful in helping learners predict words were not used by most of the teachers; only PRITBf reported that she used word recognition strategies. She also focused on expanding the learners' vocabulary, was more prepared and had the advantage of years of teaching experience. PRITBf explained new words to be learnt by using colourful wall charts. Learners need to use word recognition as a strategy for pronouncing and interpret unfamiliar words.

In the public schools the picture looked different. PRITBf furthermore, reported that the focus on phonemic awareness is not prominent and does not receive the attention it should. Pronunciation was only addressed when learners made mistakes and phonics instruction and phonemic awareness were not practised. The private school teachers' responses showed that their English language teaching practices could also be improved in some areas. All teachers must be encouraged to pay attention to word recognition and again use phonics and sight words (DoBE, 2008:75)

PRITcm was of the opinion that:

'Spelling should from part of dealing with the reading passage. In Grade 12 there is not really much time to practise word attack skills and spelling. Our primary focus is more on teaching the content and managing the prescribed syllabus.'

The overall awareness of the spelling of words was that the approach was teacher-driven as observed in the public schools and learners were not really practising and communicating with their peers regarding the repetition of spelling words. The spelling of words was also not contextualised or used as a focus in creative writing tasks due to a lack of time. By communicating with their peers in English, all learners could have the opportunity to report back in written or oral form to their peers which could make learners more accountable for their own learning.

Only one teacher focused on the use of pictures to help to clarify the meaning of the words. PRITBf said:

'I use pictures to indicate the meaning of spelling words as it helps the learners to make connections. I also code-switch sometimes if I can see it will help them to understand English better.'

PUTBf (Public school) suggested that:

'Spelling is very important in teaching vocabulary as once they know the spelling of the words it means that they can count on the words as permanent knowledge which is easier to recall than words that they do not frequently pay attention to. If they can recognise the vocabulary, reading and speaking would be easier.'

It was clear that the repetition of core vocabulary was a speaking and reading strategy that received attention. However, using the new spelling words in writing and recognising these words in texts were problematic because the learners did not have a school library where they might be exposed to reading books, thereby encountering the words they had learnt to spell.

Other areas that posed problems were the sentence order and the level of vocabulary as learners could not find many synonyms for single words. Vocabulary branching was a 
definite area that called for internalisation of more equivalents. The habit of adding pronouns where they should be omitted could be avoided and corrected by regularly reading aloud from books pitched at the learners' level.

PUTAm (Public school) said:

'Language is important because we use languages in various areas, for example, reading boards and studying other learning areas. It is an accomplished fact that when a learner reads their vocabulary will help increase knowledge.'

The qualitative data revealed that learners in private schools had an advantage when it comes to parental support. The academic qualifications of the parents of private school learners were reported to be higher than those of public schools. The parents of the learners who attended the public schools were not academically oriented, whereas the parents of the CBD schools were focused on education and the development of the learners' skills. The comparison between the public and private school environments revealed that the parents at the private schools had a slightly more favourable stance towards learning English which can be ascribed to their involvement in the CBD through their jobs. The public-school parents were less involved since they were more focused on the immediate needs of the family; they expected their children to work on the farms in the afternoons as well. The learners in the private schools had the advantage of being taught using technology, had televisions in their classrooms and enjoyed a more visual approach to teaching speaking; the public-school learners did not even all have cell phones and consequently access to the internet was a problem for them. The large number of learners per class was reported to pose a problem when doing oral exercises.

\section{CONCLUSION}

The limitations of the study were that only a small sample was selected - only four schools participated. Seden and Svaricek (2018) admitted that giving oral marks to students involve a subjective element, therefore it can also be regarded as a limitation. Assessing oral marks must be strengthened by providing support to teachers when assessing, e.g., workshops on how to do oral assessment since oral assessment is part and parcel of the CAPS prescriptions (DoBE, 2015).

This article aimed to show the oral English proficiency of Grade 12 learners and comparing the performance in private and public schools. Given that South Africa is a multilingual country, the practice of many languages should be promoted, especially English since it is the medium of instruction at schools and is used as a business language. To improve oral proficiency regarding the problem area of unprepared speech, language exposure and more regular contact with the target language vocabulary can make a definite improvement.

It is recommended that secondary schools have competitions such as debates and prepared speech competitions adjudicated by experts in English to encourage learners who study English as additional language to speak the language. Secondary schools can also provide awards to learners who perform well in English as a subject, since the awards may have a strong motivational impact. English teachers should motivate their learners to speak English by highlighting its importance for their future employment prospects. 
In conclusion, teachers will eventually focus on the value of vocabulary branching and encourage second language learners to communicate with English mother tongue speakers to facilitate English oral proficiency.

\section{REFERENCES}

ANON, HL. 2015. Public school. Private school. Business Tech, January, 19:1. Available from https://businesstech.co.za/news [Accessed: 20 May 2017]

ANGERMEYER, PS. 2015. The handbooks of sociolinguistics: Defining and dividing the field. Journal of Sociolinguistics, 19(1):91-104.

BADDELEY, AD. 2003. Working memory and language: An overview. Journal of Communication Disorders, 36:189-208.

BALL, P. 2017. The English language in South Africa. The heritage portal. Available from http://www.theheritageportal.co.za/article/english-language-south-africa [Accessed: 20 February 2018]

BARNARDO, C. 2017. Business in society conference: IMVOLA. Wanderers club, Johannesburg.

BLESS, C., HIGSON-SMITH, C. \& SITHOLE, SL. 2013. Fundamentals of social research methods. An African perspective. Hatfield: Van Schaik Publishers.

BLOOMFIELD, S. \& LEONARD N. 2000. Task-related variation in interlanguage: The case of articles. Language Learning, 38:21-44.

BOEIJE, H. 2002. A purposeful approach to the constant comparative method in the analysis of qualitative interviews, Quality and Quantity, 36:391-409. Available from https://doi.org/10.1023/A:1020909529486 [Accessed: 2 May 2018]

BRONFENBRENNER, U. 1976. The experimental ecology of education, Educational Researcher, 5(9):5-15. Available from http://www.jstor.org/stable/1174755 [Accessed: 8 April 2017]

BRONFENBRENNER, U. 1979. The ecology of human development: Experiments by nature and design, Harvard University Press, Cambridge, MA.

BRONFENBRENNER, U. 1986. The relationships among working memory, math anxiety and performance. Journal of Experimental Psychology, 1(1):234-240.

BRONFENBRENNER, U. 1994. Ecological models of human development. Readings on the development of children, 2:37-43.

BROWN, HM. 2007. Looking back: Student attitudinal change over an academic year. The Language Teacher, 23, 28-34.

BROWN, MH. 2001. Meaning and Textuality. Frank Collins and Paul Perron, Toronto: University of Toronto Press.

BROWN, MH. 2004.The preference for self-correction in the organization of repair and conversation. Toronto: University of Toronto Press.

BYLUND, E. \& OOSTENDORP, M. 2014. Second language acquisition. In: Bock, Z \& Mheta, G. Language, society and communication. pp. 255-278. Hatfield: Van Schaik Publishers.

CHOU, WE. 2015. Metacognitive online reading strategy use: Reader perceptions in solutions. South Africa rural educator, 1(10):193-101.

CLASSEN, RE. 2010. Reading difficulties instruction and assessment. $1^{\text {st }}$ ed. New York: McGraw Hill.

COLOMBO, M. \& FURBUSH, D. 2009. The effects of extracurricular activity, ethnic identification, and perception of school on student dropout rates. Hispanic Journal of Behavioural Sciences, $21,31$.

CONSOLI, S. \& AOYAMA, T. 2020. Longitudinal L2 motivation inquiry: a response to Lamb's (2016) 'when motivation research motivates: issues in long-term empirical investigations'. Innovation in Language Learning and Teaching, 14:2, 178-187.

COOK, YO. 2001. Platinum social sciences. Platinum, 2(2):33-37.

CUMMINS, UY. 2001. General educators' attitudes towards students with mild disabilities and their use of instructional strategies. Remedial and special education, 20:17-35.

DAN, JL., SMATT, PK. \& PERKIN, KK. 2015. Historia Animalium. Volume 1. London: Heineman. 
DBE, 2008. National Curriculum Statement, Department of Basic Education.

DBE, 2011. National Curriculum Statement, Department of Basic Education (English First Additional Language). pp7-10. Cape Town: Government printing Works.

DBE. 2012. National Curriculum Statement. Social-motivational processes and interpersonal relationships: Implications for understanding motivation at school. Journal of Educational Psychology, 91, 8- 18.

DBE, 2015. Academic press and sense of community: Conflict, congruence, and implications for student achievement. Social Psychology of Education, 1:7-10). Pretoria: DoBE printers.

HENRY, PT. 1998. Qualitative research. A guide to design and implication. San Francisco: Jossey Bass.

HORTSHEMKE, K., SIYKWAZI, P., WALTON, E. \& WOLHUTER, C. 2013. Education studies. History, Sociology and Philosophy. Cape Town: Oxford publishers.

IBRAHIM, NM., OSMAN, YF. \& BACHOK, AQ. 2014. Good practice for pupils learning English as an additional language: Lessons from effective literacy teachers in inner-city primary schools. Procedia Social and Behavioural Sciences, 7:274-285.

KLAPWIJK, N. 2015. Emc2=comprehension: a reading strategy instruction framework for all teachers. South African journal of education, 35(1):1-9.

LEONARD, J. 2011. Using Bronfenbrenner's Ecological Theory to Understand Community Partnerships: A Historical Case Study of One Urban High School. Urban Education, 46(5):9871010. Available from: http://uex.sagepub.com. [Accessed: 02/02/2019]

MAREE, K. 2007. Doing qualitative research: A practical handbook. London: Sage publications.

MCROY, TJ. 2009. Practical research: Planning and design. $9^{\text {th }}$ edition. London: Kevin \& Daris.

NEL, N \& MÜLLER, H. 2010. The impact of teachers' limited English proficiency on English second language learners in South African schools. South African Journal of $\quad$ Education, 30:635650.

NIAGO, KM. 2010. Practical guide to facilitating language learning. Cape Town: Oxford University Press.

NIEWENHUIS, TH. 2013. Reflective narratives and the emergence of identity. New York: Routledge.

OOSTENDORP, M. 2013. First language acquisition. (In: Bock, Z \& Mheta, G. Language, society and communication. pp. 225- 254. Hatfield: Van Schaik).

RAO, PS. 2019. The importance of speaking skills in English classrooms. Alford Council of International English \& Literature Journal(ACIELJ), 2(2):6-18.

RED. 2018. 8 Ways Nelson Mandela changed the world. Available from https://www.red.org/reditorial/2018/7/18/8-ways-nelson-mandela-changed-the-world. [Accessed: 8 March 2021]

RENARD, L. 2019. Direct instruction: A practical guide to effective teaching. Published online: Available from https://www.bookwidgets.com/blog/2019/03/direct-instruction-a-practicalguide-to-effective-teaching. [Accessed 2 March 2021]

SADEGHI, K. \& RICHARDS, JC. 2015. Teaching spoken English in Iran's private language schools: Issues and options. English teaching practice and critique, 14(2):210-215.

SEDEN, K. \& SVARICEK, R. 2018. Teacher Subjectivity Regarding Assessment: Exploring English as a Foreign Language Teachers' Conceptions of Assessment Theories that Influence Student Learning. CEPS Journal, 8(3):110-139. doi: 10.26529/cepsj.500.

SETATI, RR. 2001. A paradigm shift in counseling philosophy. Counseling today, 8(2):253.

SCHMITT, N. \& UNDERWOOD, G. 2004. Exploring the processing of formulaic sequences through a self-paced reading task. In Schmitt, N. ed. Formulaic Sequences Acquisition, processing and use. pp.173-189. Amsterdam: John Benjamins Publishing Company.

SPRATT, FM. 2005. Exploring the processing of formulaic sequences through a self-paced reading task. London: Oxford Publishers.

STATISTICS SA, 2015. District in Detail: Soshanguve. Available from https://www.southafricanmi.com/soshanguve-in-detail.html. [Accessed: 17 July 2021]

STROUD, C. 2014. Linguistic diversity and its discontents. pp. 297-311. (In: Bock, Z. \& Mheta, G. 2014. pp. 297-312. Language, society and communication. Pretoria: Van Schaik).

Per Linguam 2021 37(1):79-96

http://dx.doi.org/10.5785/37-1-973 
TAVIL, ZM. 2009. Parental attitudes towards English education for kindergarten students in Turkey. Kastamonu Education Journal, 17(10):331-340.

VAN DER WALT, C. EVANS, R. \& KILFOIL, W. 2009. Learn to teach. English language teaching in a multilingual context. Hatfield: Van Schaik Publishers.

WELMAN, K. KRUGER, F. \& MITCHEL, E. 2005. Social research methods. (4 ${ }^{\text {th }}$ edn.). London: Oxford University Press.

WESSELS, TR. 2010. Key issues in bilingualism and bilingual education. Clevedon, Avon: Multilingual Matters.

WOLHUTER, C. 2013. The education system of South Africa: Catapulting the country into the twenty-first century. In: Horsthemke, K., Siyakwazi, P., Walton, E. \&Wolhuter, C. Eds. Education studies. History, Sociology and Philosophy. pp.102-121. Hatfield: Van Schaik Publishers.)

YACOOB, NA. OSMAN, MM. \& BACHOK, S. 2014. Factors Influencing Parents' Decision in Choosing. Private Schools -Social and Behavioral Sciences, 153:242-253.

\section{BIOGRAPHICAL NOTES}

Lina Vukosi is a lecturer at TUT and she is currently working on her doctoral study. Her field of interest is teaching at school and language matters. She is the main author of the study as the work was published from her Master's.

Cornelia Smith is a lecturer at TUT in the Department of Applied Languages. She is interested in English in education. She has a PHD in English and her research foci are language in education and English. She was the main supervisor of the student and assisted with the writing.

Eunice Rautenbach lectured at TUT and is currently self-employed; she is interested in linguistics and qualitative research. She was the co-supervisor of the study.

Gary Collins is interested in English and technology and is the HOD of the Department of Applied Languages at TUT. 